
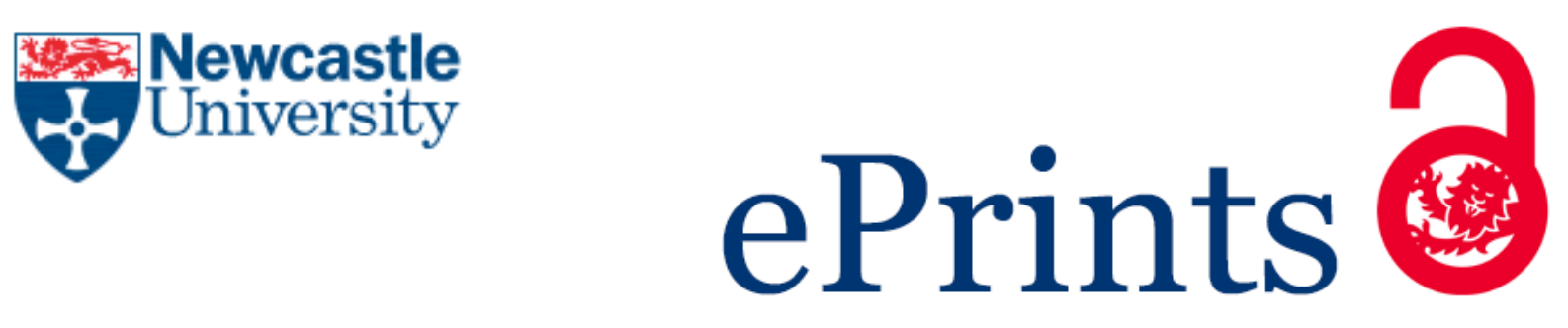

Clemente M, Gabbioneta C.

How Does the Media Frame Corporate Scandals? The Case of German

Newspapers and the Volkswagen Diesel Scandal.

Journal of Management Inquiry (2017)

DOI: https://doi.org/10.1177/1056492616689304

\title{
Copyright:
}

This is the authors' accepted manuscript of an article that has been published in its final definitive form by Sage Publications, 2017.

DOI link to article:

https://doi.org/10.1177/1056492616689304

Date deposited:

$17 / 02 / 2017$

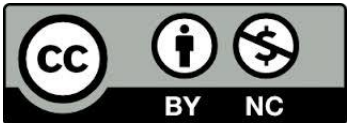

This work is licensed under a Creative Commons Attribution-NonCommercial 3.0 Unported License 
How Does the Media Frame Corporate Scandals?

The Case of German Newspapers and the Volkswagen Diesel Scandal

\author{
Marco Clemente* \\ Aalto University \\ Email: marco.clemente@ aalto.fi \\ Mobile: +358.503431478 \\ Claudia Gabbioneta \\ Newcastle University \\ Email: claudia.gabbioneta@newcastle.ac.uk
}

* Corresponding author 


\title{
How Does the Media Frame Corporate Scandals? The Case of German Newspapers and the Volkswagen Diesel Scandal
}

\begin{abstract}
Despite the importance that the media has in regards to influencing people's perceptions of wrongdoing, organizational scholars have paid little attention to how the media reports wrongdoing. This article starts to address this gap by considering how the media frames corporate scandals. We empirically examine how four different German newspapers reported on the Volkswagen diesel scandal. We inductively identify the constitutive elements of a general corporate scandal frame. Then, we analyze how each newspaper framed the scandal through combinations of different elements. We identify from our dataset four frames of corporate scandals that newspapers applied: legalistic, contextual, reputational, and scapegoating. Our article testifies to the importance of cross-fertilization between research on mass communication and political science on the one side, and organizational research on the other side and, more generally, it calls for more attention to be given to the media in the study of scandals and organizational wrongdoing.
\end{abstract}

Keywords: scandal, wrongdoing, media, framing, Volkswagen 


\section{How Does the Media Frame Corporate Scandals? The Case of German Newspapers and the Volkswagen Diesel Scandal}

\section{Introduction}

While organizational wrongdoing has been recognized as a key research topic since the early stages of organizational and management literature (Boulding 1958), its appearance has subsequently been more sporadic (Palmer, Smith-Crowe, and Greenwood 2016). However, academic and public interest towards organizational wrongdoing has increased substantially in recent years (Diestre and Rajagopalan 2014; Gabbioneta et al. 2013; Palmer et al. 2016; Paruchuri and Misangyi 2015; Vaughan 1999), probably influenced by the known corporate scandals such as those of Enron, WorldCom, and Parmalat. A recent perspective on wrongdoing is to conceive it as being socially constructed (Greve, Palmer, and Pozner 2010; Palmer 2012). According to this perspective, wrongdoing is the result of a two-way interaction between organizations and social-control agents. The latter entities have the institutional role of drawing the lines that define legal, ethical, and socially responsible behaviors and assessing whether companies have trespassed over such lines (Greve et al. 2010). Social-control agents include the state and professional associations, which have direct sanctioning power over companies, but they also comprise other organizations that can impact the image and the reputation of the affected companies, thus inflicting indirect social or economic costs. The media represents an exemplary case of the latter group.

The role of the media is fundamental to the knowledge and perception of organizational wrongdoing for at least two reasons. First, the media can act as the main publicizer of a transgression that other social-control agents have ratified, making the misbehavior known to the general public. Second, and more importantly, 
the media has the power to influence the perception of a transgression through applying different frames. Following a constructivist approach, a behavior becomes a transgression only if it is perceived as such. Therefore, media framing is key in the social construction of wrongdoing, even without the actions of other social-control agents. The media influences the perception of a transgression, its magnitude, and its consequences.

The role of the media in the social construction of wrongdoing is particularly evident in the case of scandals. Scandals can be highly consequential events for the organizations involved in the wrongdoing, their affiliations (Jensen 2006), and can even lead to broader institutional change at the societal level (Clemente, Durand, and Roulet, forthcoming). The media is the discriminating variable that discerns between a transgression that progresses into a scandal and the many transgressions that remain buried in the mass of daily news. Scandals are highly-mediated events that originate from a disruptive publicity of a transgression (Adut, 2008) that elicits public disapproval (Thompson, 2000). This can happen only when the media provides enough attention to the transgression and when the media applies a scandal frame which presents the transgression as something that challenges existing norms and needs a remedy (Entman, 2000).

Despite the importance of the media in the social construction of organizational wrongdoing, and of scandals in particular, few studies in the organizational and management literature have specifically looked at the role played by the media in framing (and thus influencing the interpretation of) organizational wrongdoing (Cohen et al. 2015; Jonsson, Greve, and Fujiwara-Greve 2009; Roulet 2015). To study the connection between media framing and organizational wrongdoing, we turn to political and mass communication research. This research has a long tradition in 
studying media framing (Lippmann 1922). More recently, a few studies have directly examined how the media frames instances such as crises or scandals (Clemente, Durand, and Porac 2016). However, current studies mostly consider scandals in the contexts of politics or sports, leaving understudied the question of how framing occurs in other types of settings (Whetten 1989), such as the corporate setting.

This article brings together political and mass communication research with research on organizational wrongdoing to investigate how the media frames corporate scandals. We do so by first identifying the elements that constitute a general media frame of corporate scandal and then by understanding how the combination and relative saliency of such elements can give rise to different frames. We focus on newspapers, as they are among the most influential media (Katz, Haas, and Gurevitch 1973) and play a crucial role in forming public opinion (Entman 2012). Our setting is the diesel scandal involving the Volkswagen Group (hereafter VW) that was made public in September 2015. We analyze the media articles of the scandal written by four different German newspapers_-two national and two regional—and search for common elements and variations in the frames that were applied to the scandal.

We find that seven key elements were used to frame the VW corporate scandal: nature of the scandal, identification of social-control agents that judge the misbehavior, locus of responsibility, discussion of the reputational costs of the scandal, discussion of the financial costs of the scandal, consideration of potential spillover effects, and suggestion of possible repairing actions. Different combinations of these elements give rise to different media frames. In our case, we find four different types of frames: legalistic, contextual, reputational, and scapegoating. Our findings contribute to the research on organizational wrongdoing as well as to the research on media framing in the political and mass communication literature. 


\section{Theoretical Background}

\section{Research on Organizational Wrongdoing}

Research on organizational wrongdoing has gained traction in the last 10 to 15 years, partially as a consequence of the wave of scandals that hit society and the economy at the turn of the century, along with an increased perception of the ubiquity of wrongdoing in today's society (Misangyi, Weaver, and Elms 2008). Much of this research investigated the antecedents of organizational wrongdoing, such as strain or culture. Strain theory (Merton 1938) posits that, when actors are not able to achieve their goals through legitimate means, they resort to wrongdoing to achieve them. For example, organizations facing poor results may engage in wrongdoing in order to acquire the resources they need to operate (Clinard and Yaeger 1980; Staw and Szwajkowski 1975). Another main cause of organizational wrongdoing that has been extensively studied is organizational culture (Greve et al. 2010). Several studies indicate that organizational culture can endorse wrongdoing. For example, wrongdoing can be encouraged by rewarding the achievement of ambitious ends without much consideration for the means used to achieve them (Kulik 2005; Sims and Brinkmann 2003).

A different set of studies investigated the consequences of organizational wrongdoing and suggested that the discovery of wrongdoing tends to have adverse consequences for the organization that engages in the wrongdoing, for the individuals within the organization, and for other organizations. As for the organizations that resort to wrongdoing, research shows that they suffer reputational consequences on top of legal punishment, as measured by a loss in the stock value beyond what can be 
explained by fines and restitutions (Karpoff, Lee, and Vendrzyk 1999; Sullivan, Haunschild, and Page 2007). Research has also provided evidence of significant labor market penalties for individuals involved in wrongdoing, including losing their position at the organization, their seats on other boards, or having difficulty finding an equivalent job (Desai, Hogan, and Wilkins 2006). Finally, previous studies in the field show that the negative consequences of organizational wrongdoing can spread to other organizations that are seen as associated with the offender (Adut 2008; Jonsson et al. 2009; Paruchuri and Misangyi 2015) or even unveil existing latent conflicts in society which then lead to field-level institutional change (Clemente, Durand, and Roulet forthcoming).

More recently, a new perspective has emerged that looks at organizational wrongdoing as socially constructed (Greve et al. 2010; Palmer 2012). According to this perspective, wrongdoing is the result of a two-way interaction between companies and social-control agents. Social-control agents are organizations that have the institutional role of drawing the lines that define legal, ethical, and socially responsible behaviors, and of assessing whether or not companies have trespassed over such lines (Greve et al. 2010). Social-control agents include entities such as the state and professional associations that have direct sanctioning power toward companies; however, social-control agents also include other organizations (such as rating agencies and the media) that can impact the image and reputation of the affected companies, inflicting indirect social or economic costs. This stream of research is mostly interested in the social construction of wrongdoing and, in particular, understanding why some behaviors are labeled as wrongdoing while other similar ones are not. 
Our study contributes to this recent stream of research by considering the role of the media in influencing whether the public perceives the organization as engaging in wrongdoing, as well as in influencing the public's interpretation of the wrongdoing. Few studies in organizational research have looked at the role of media in influencing the public's perception of organizational wrongdoing. For example, Cohen, Ding, Lesage, and Stolowy (2015) investigate how the media frames the role of auditors in corporate fraud cases, and provide evidence that the media contributes to reinforcing the idea that audit firms are the main responsible parties for the wrongdoing. Further, Roulet (2015) demonstrates how the frames used by the media help to diffuse the stigma over the financial industry. Notwithstanding this research, media framing is still an understudied theme in organizational research (Clemente, Durand, and Porac 2016; Fiss and Hirsch 2005). Therefore, in order to understand the role of framing in organizational wrongdoing, we consider research in the areas of political science and mass communication.

\section{Research on Media Framing}

Research in political science and mass communication has long recognized the role of the media in influencing the public's interpretation of relevant issues. Several studies have provided evidence that the media shapes public opinion in several ways, especially through framing (Entman and Rojecki 1993; Entman 1993; Fiss and Hirsch 2005; Gamson and Modigliani 1989; Jörg Matthes 2009; Pan and Kosicki 1993). The concept of framing has become increasingly important in this literature, to the extent that the Journalism \& Mass Communication Quarterly mentions that "[o]ne of the most fertile areas of current research in journalism and mass communication involves the concept of "framing"' (Riffe 2004 2). Despite its diffusion, there is a lack of consensus on a unique definition of framing (Joerg Matthes, and Kohring 2008). 
Framing is generally defined as "the process by which a communication source, such as a news organization, defines and constructs a political issue or public controversy" (Nelson, Clawson, and Oxley 1997). More specifically, many authors refer to the definition of framing in the seminal article of Entman (1993): "Framing involves selection and salience. To frame is to select some aspects of a perceived reality and make them more salient in a communicating text, in such a way as to promote a particular problem definition, causal interpretation, moral evaluation, and/or treatment recommendation" (Entman 1993 52). In our paper we adopt this definition of framing.

Many studies prove the influence of framing on public opinion (An and Gower 2009). For example, Gamson and Modigliani (1989) show that changes in media discourse on nuclear power go "hand in hand" with changes in public opinion on the same issue. Iyengar (1990) states that the media's focus on individual cases rather than on broader social trends has consequences regarding how the public makes attributions about the causes of, and solutions to, social problems such as poverty and crime. Nelson and Kinder (1996) find that framing issues in a way that draws more or less attention to a policy's beneficiaries is a way to influence the attitude that people have about government policy.

Media frames are particularly important in the case of crises, as they can mobilize public opinion in favor of one of the parties involved (An and Gower 2009; Garcia 2011). Garcia (2011) examines the 10-year conflict between British Petroleum (BP) and Greenpeace through a qualitative framing analysis of the content of US newspapers. She finds that, overall, newspapers portrayed BP as a villain, while Greenpeace was usually the hero that is highly credible and has minimal cause for the assignment of attribution, despite its high level of involvement in the conflict. An and Gower (2009) analyze the type of frames that are primarily used in crisis news 
coverage. They use the typology of frames developed by Semetko and Valkenburg (2000), who investigated the period of time surrounding the meeting in Amsterdam of European heads of state in 1997. This typology comprises the attribution of responsibility, which is a "a way of attributing responsibility for [a] cause or solution to either the government or to an individual or group" (Semetko and Valkenburg 2000 96); a conflict frame, which reflects conflict or disagreement between actors; an economic frame, which focuses on the economic consequences for individuals, organizations, and other actors; human interest, which "brings a human face or an emotional angle to the presentation of an event, issue, or problem" (Semetko and Valkenburg 2000 95); and a morality frame, which positions an event or an issue in the broader context of morals or norms.

Scholars have also studied the role of media in particular in scandals, mostly in the political and sporting context (Bennett, Lawrence, and Livingston 2006; Harlow 2012; Joslyn 2003; Kepplinger, Geiss, and Siebert 2012; Owen 2000; Sanders and Canel 2006; Stepanova and Strube 2009; Yang 2014). Harlow (2012) analyzes the media coverage of Brazil's, then president, Luiz Inácio Lula da Silva, who was implicated in a bribery scandal in 2005 , and shows that the coverage of the scandal was influenced by the ownership of the newspapers. Kepplinger, Geiss, and Siebert (2012) analyze four scandals affecting German politicians or governments, and link media framing and scandal literature by examining how media frames influence the way in which individuals make sense of scandals-focusing in particular on the cognitions, emotions, and opinions associated with the scandal. Entman (2012) goes further to propose that a scandal originates not only when the media publicizes a transgression — as already proposed by other authors (Adut 2008; Thompson 2000) — but also when the media applies a scandal frame. In Entman's theory (2012), a media 
frame is a necessary condition for a scandal to originate. In his studies of US politics, he shows that US presidential scandals originated only when media framed a certain presidential behavior in a way that include four elements: problem definition, moral judgment, causal analysis, and endorsement of a remedy (Canel and Sanders 2006; Entman 2012; Entman, Jörg Matthes, and Pellicano 2009).

Research has also considered scandals in sports and investigated how newspapers from different media outlets portrayed a scandal, usually by taking the side of the party with which they are "entangled"-meaning the social and economic proximity to the actors involved in the scandal (Clemente, Durand, and Porac 2016). Stepanova and Strube (2009) analyze the media coverage of the 2002 Olympics figure skating scandal that involved the Canadian and Russian teams. They find that American newspapers took a pro-Canadian position, whereas Russian newspapers took the side of the Russian team. They attribute this to ideological motives. Yang (2014) analyzes how two prestigious US newspapers-the New York Times and the Washington Post-analyzed state-sponsored cheating in the 2008 Beijing women's gymnastics competition, and shows how the US journalists positioned the event as part of a larger debate on China's refusal to adhere to Western standards.

Previous literature has mostly focused on scandals in political and sports contexts, thereby leaving open the question of how the media frames scandals in other contexts. We adopt the concept of a scandal frame from research in the political science and communication literature and apply it to corporate scandals. Our research question is: How does the media frame corporate scandals?

\section{The Volkswagen Diesel Scandal}


We study our research question by considering the case of the VW diesel scandal that abruptly hit the headlines in September 2015. On September 18, 2015, the United States Environmental Protection Agency (EPA) issued a notice of violation of the Clean Air Act to VW, after real-life tests revealed much higher carbo-emission levels than those registered in the laboratory tests run by the company. The turbocharged direct injection (TDI) diesel engines produced by VW were found to emit up to 40 times more nitrogen oxide (NOx) in real-world driving than in laboratory tests. These levels of NOx greatly exceeded the US standards on carbo-emissions.

Allegations started to circulate that the company had intentionally programmed its TDI diesel engines to activate certain emission controls only during laboratory testing. Apparently, when it detected an emissions test, the engine control switched from good fuel economy and high NOx emissions to a low-emission, compliant mode. This caused the engine to emit NOx levels above limits in daily operation but to comply with US NOx standards when being tested in a laboratory setting. Although VW's managers initially declared their surprise at finding out that such a device had been installed on the company's cars, many argued that the company's management should have known about it for years. Several German newspapers stated that “...either the firm's management is highly incompetent, or they should have known what was going on inside the company" (Das Bild, 04, translation by the authors). The company management eventually admitted that they were aware of the manipulation.

VW soon became the target of regulatory investigations in multiple countries, and the value of the company's stock decreased by a third in the days immediately after the news. VW CEO Martin Winterkorn resigned. Head of brand development HeinzJakob Neusser, Audi research and development head Ulrich Hackenberg, and Porsche research and development head Wolfgang Hatz were suspended and subsequently 
resigned. VW announced plans to spend $\$ 7.3$ billion US on rectifying the emissions issues and to refit the affected vehicles as part of a recall campaign.

\section{Methods and Data}

\section{Data Collection}

To analyze how the media framed the VW scandal, we collected all of the articles about VW that were published by four different German newspapers in the week following the exposure of the scandal (specifically from September 18 to September 24, 2015). We focused our analysis on the articles published in the week after the scandal was made public because previous research suggests that the first days following the exposure of a transgression are key to understanding if and how a transgression leads to a scandal (Entman 2012; Thompson 2000). It is, in fact, during the first days, that interpretative frames emerge, start to affect public evaluations, and dictate how the transgression will be interpreted.

We selected two newspapers with a national circulation and two with a regional circulation, because previous research found that newspapers having different levels of entanglement with the wrongdoer frame the scandal in different ways (Clemente, Durand and Porac 2016, Stepanova and Strube, 2009). One of the national newspapers_Das Bild (circulation in 2014: 2,099,909 copies)—is considered a rather conservative, right wing publication" ${ }^{1}$ (IVW, 2015) and is "notorious for its mix of gossip, inflammatory language, and sensationalism" (Steininger 2012). The other national newspaper-Die Süddeutsche Zeitung (circulation in 2014: 381,844

\footnotetext{
${ }^{1}$ Information on the newspapers was retrieved from the website www.ivw.de.
} 
copies)—is generally seen as a center-left/left-liberal or critical-liberal newspaper (IVW, 2015), broadly supporting the Social Democratic Party of Germany (SPD).

The two regional newspapers that we selected are headquartered in the two cities in which VW has the largest number of employees. Die Wolfsburger Allgemeine Zeitung (circulation in 2014: 35,955 copies) is based in Wolfsburg, the city in which VW was founded and which today accounts for over $28 \%$ of the company's workforce (61,495 employees, as per the company's website). Der Donaukurier (circulation in 2014: 85,496 copies) is based in Ingolstadt, the second largest production site of VW (accounting for around 18.5\% of the company's workforce.

To collect the articles, we visited the websites of the selected newspapers and searched their archives for articles that were published in the time period under investigation and that mentioned "Volkswagen" in their text. We then read all the articles resulting from our search to make sure that they were related to the Volkswagen diesel scandal. This led to the exclusion of six articles that, despite containing the word "Volkswagen," were not related to the scandal ${ }^{2}$. Finally, we downloaded the articles and saved them in a folder. In whole, we found 170 articles published by the four newspapers the week after the scandal was exposed: 40 articles published in Das Bild, 32 articles published in Die Süddeutsche Zeitung, 65 articles published in Die Wolfsburger Allgemeine Zeitung, and 33 articles published in Der Donaukurier.

\section{Data Analysis}

\footnotetext{
${ }^{2}$ Four articles reported on new car models being launched, without any mention of wrongdoing. Two articles were about car accidents in which the company's cars were involved.
} 
Given the nature of our research question, we used an inductive methodology to derive our frames. According to the definition of framing adopted in this study, framing involves both selection and salience. Therefore, to identify the media frames, we started by identifying "components or devices of frames" (selection), whose relative saliency give origin to a media frame (Joerg Matthes and Kohring 2008 263). We followed a two-stage approach. In the first stage we used the Gioia methodology—commonly used in qualitative organizational studies — that can provide an alternative qualitative methodology for media framing research. The Gioia methodology differs from other empirical methods as they do not start with a predetermined number of frame elements - typically problem definition, causal attribution, moral evaluation and treatment (Entman 1993; Joerg Matthes and Kohring 2008). Rather, they let the elements emerge from the texts being analyzed. In this case, the Gioia methodology helped us find elements that are specific for corporate scandals and that have not been identified in prior studies carried out in different research contexts.

We applied the Gioia methodology following the standard procedure in the literature (e.g. Corley and Gioia 2004; Gioia and Chittipeddi 1991). We started by reading all of the articles in order to develop a general understanding of their tone and content, which helped us develop preliminary insights on the frames used by the media. Then, we manually coded our articles. We started with one newspaper and then moved onto the next one. Initially, we used open coding to uncover common themes and produce an initial set of categories (Glaser and Strauss 1967; Locke 2001). We then discussed our preliminary codes and combined those that were, in essence, similar (although varying in specific terms) into first-order categories. Once we had developed a set of first-order categories for the first newspaper, we moved 
onto the second one. We applied our first-order categories to the second newspaper as a way of testing, refining, and extending early interpretations (Glaser and Strauss 1967), but we also allowed new categories to emerge. The latter were then applied to the first newspaper, in what can be thought of as an iterative process. We applied the same methodology to all of our newspapers, using a combination of categories that had previously been identified and categories that emerged during the analysis. This initial round of coding produced twenty-one first-order categories that were featured in one or more newspapers.

Next, we compared first-order categories across newspapers. Observed commonalities among first-order categories led us to combine them into fewer, broader groupings - second-order categories — that collectively offered a theoretical framework for analyzing how the media frames organizational wrongdoing. This extra round led us to eliminate five first-order categories that were not featured consistently across the newspapers, and to group the remaining sixteen categories into seven second-order categories. Figure 1 depicts the resulting data structure, presenting the first-order categories and their relationship to second-order categories.

Insert Figure 1 about here

In the second stage, we analyzed each newspaper and investigated which firstorder categories each newspaper gave more saliency. Observed differences in the salience of first-order categories across newspapers led us to identify the distinct frames that each newspaper used in reporting on the VW scandal. These frames are illustrated in detail in the results section. 


\section{Results}

\section{Key Elements in Media Frames of Organizational Wrongdoing}

We identified seven elements that are key to explaining how the media frames organizational wrongdoing. We discuss each of them below. All quotes cited in this analysis were translated from German by one of the authors.

Nature of the Scandal. The first element that we identified concerns the nature of the wrongdoing in which the company was involved. Most of the newspaper articles that were analyzed saw the company as being responsible for having installed software that is able to detect whether a car is being tested. Das Bild, for example, noted how:

"The Environmental Protection Agency (EPA) announced in Washington on Friday that the company is suspected of having used special software to manipulate the evaluation of pollutant emissions" (Das Bild, 03),

and Die Wolfsburger Allgemeine Zeitung explained that:

"Europe's largest carmaker, Volkswagen, has admitted to having installed eleven million motors...fitted with software meant to manipulate the cars' emissions" (Die Wolfsburger Allgemeine Zeitung, 61).

Surprisingly, a limited number of articles considered the environmental and health implications of the company's wrongdoing. Those that did mention these implications generally reported a short statement by an EPA employee who argued that "using such means to circumvent the climate protection standards is illegal and a threat to public health" (Die Süddeutsche Zeitung, 02). 
Social-Control Agents' Judgment. The second element we identified refers to which social-control agents the media report as criticizing VW. Social-control agents are key in the dynamics of a scandal because they have the public role of monitoring companies - assessing whether they have trespassed over the line of legally, socially, and ethically acceptable behaviors - and either sanctioning the wrongdoer directly or influencing future social or economic sanctions.

Regulators. All of the newspapers mentioned the EPA as the organization that identified the wrongdoing by issuing a notice of violation of the Clean Air Act:

"The company was suspected to have used special software to manipulate the measurement of pollutant emissions, said the Environmental Protection Agency (EPA) in Washington” (Das Bild, 01).

Government officials. In addition, newspapers also reported statements from officials of the US Government that blamed VW for its behavior. The VW scandal seemed to also have become a political case.

"Even the government intervened: We are "quite concerned" about the behavior of VW, said a spokesman of President Obama” (Süddeutsche Zeitung, 15).

Locus of Responsibility. The third element that we identified-the locus of responsibility—has to do with the identification of the principal culprit responsible for the wrongdoing. The newspaper articles identified either the CEO and other company executives, or the industry in which the company operates, as the main culprits.

CEO and executive responsibility. In most cases, the CEO of VW was identified as the culprit. Although he may or may not have been directly implicated in the 
wrongdoing, he was held responsible because of his role and position within the organization. Many of the newspaper articles that we analyzed bluntly concluded that:

“Winterkorn [Volkswagen's CEO], who is also in charge of the company's research and development, should have either known about the manipulation or should have been aware of it, which means that he did not have control over the company... In either case... he is no longer an acceptable part the of management team" (Das Bild, 04).

Sometimes, in addition to the CEO, the newspapers held other executives accountable. Das Bild, for example, considered Hackenberg_VW's Research and Development Director-and Hall—the Director of Engine Development—as being responsible for the gas-emission manipulation, as suggested by the following quote:

"By stepping down, Hackenberg and Hall took technical responsibility for the gas affair-after that Winterkorn took general responsibility for it” (Das Bild, $34)$.

Die Wolfsburger Allgemeine Zeitung echoed this view by arguing that "the Directors of development, Hackenberg and Hall, have to take technical responsibility for the gas-emission affair and step down" (Die Wolfsburger Allgemeine Zeitung, 68).

Industry responsibility. In other circumstances, the locus of responsibility was attributed to the context in which the organization operates-more precisely, to the industry in which VW competes. Several newspaper articles highlighted that other car producers had been or were under investigation for similar reasons, and that the currently used gas-emission tests created a strong incentive for all companies in the car industry to cheat. For example, Der Donaukurier says:

“... VCD [Der ökologische Verkehrsclub-The Ecological Transport Association] described the manipulations in Berlin as only the tip of the iceberg. They are sure that other corporations, in addition to Volkswagen, manipulate their emission values, and not just in the US... According to... DUH 
[Einschätzung der Deutschen Umwelthilfe - Assessment of the German Environmental Aid], other manufacturers use a technology similar to VW to manipulate exhaust emissions" (Der Donaukurier, 04).

Reputational Costs. The fourth element that we identified is the reputational costs associated with the scandal. Here it is possible to distinguish between the deterioration of the company's image resulting from the scandal and the loss of trust by relevant stakeholders.

Image deterioration. A common result of corporate scandals is the deterioration of the image of the company involved. We consistently found that many of the newspaper articles that were analyzed reported on the potential corrosion of VW's image because of the exposure of the scandal. For example, many articles noted how "for the Wolfsburgers, the cheating-affair is an image disaster" (Das Bild, 01) and how “... the Wolfsburgers' image is now seriously damaged” (Der Donaukurier, 05).

Loss of trust. Similarly, corporate scandals may damage existing relationships between the company and its stakeholders. Mutual trust plays a major role in the development and maintenance of these relationships, and corporate scandals are likely to undermine it. In this respect, many of the articles that we analyzed reported Winterkorn's speech, in which he admitted that:

"Millions of people around the world trust our brands, our cars, and our technologies. I am so sorry that we have betrayed this confidence" (Das Bild, 01).

Financial Costs. The fifth element that we identified is the financial costs associated with the scandal. The discussion of these costs involves five elements: the monetary sanctions that could have been—and, in some cases, were-inflicted on VW; the estimated costs of recalling the cars fitted with the incriminating software; 
the stock market effects of the scandal; the economic consequences of the scandal on the customer markets in which the company operated; and the impact of the scandal on the company's profits.

Monetary sanctions. The newspaper articles discussed, in detail, the monetary sanctions that could be-and in some cases were-imposed on VW. Das Bild estimated that "the accusations of manipulation could cost the company two hundred billion euros" (Das Bild, 02) and Die Süddeutsche Zeitung maintained that "VW could face penalties of up to 37,500 US dollars (around 33,000 euros) per car, totaling more than 18 billion US dollars, if the allegations were confirmed" (Die Süddeutsche Zeitung, 02).

Costs of product recalls. Another reason for concern was the possibility that the company could be asked to recall around 500,000 cars whose gas emissions exceeded the US standards. Although “the EPA made it clear that they didn't arrange any formal recall" in the week after the notice of violation was issued (Der Donaukurier, 06), there were rumors that the EPA could ask the company to do something similar in the near future. Der Donaukurier, for example, speculated that " $V W$ has to develop a plan for the conversion of the rejected models as soon as possible... The owners of these cars would be informed about the recall, once the EPA has agreed on a plan... The recall could take over a year" (Der Donaukurier, 06).

Stock market effects. The newspaper articles that were analyzed also discussed the consequences of the wrongdoing on the company's share price. In the days immediately after the notice of violation was issued to VW, the share price of the company “crashed" (Das Bild, 08). Der Donaukurier recounted how: 
"On the Frankfurt Stock Exchange, the VW share lost more than 20 percent, closing at minus 19.82 percent. On Monday the share price had already collapsed by 18.6 percent" (Der Donaukurier, 07),

to which Die Süddeutsche Zeitung added that "investors sold VW shares en-masse, as the share price fell by more than 20 percent. The market value of the automaker fell by around 14 billion euros" (Die Süddeutsche Zeitung, 05).

Consequences for the customer markets. To make the situation even worse, VW was forced to stop selling its diesel cars in the US market. The newspaper articles extensively discussed the market consequences of this interruption, and wondered whether the company was going to recover from it. Die Süddeutsche Zeitung wrote that "no one knows how much money the Group will have to spend to come back to the US market with diesel cars" (Die Süddeutsche Zeitung, 08) and Das Bild laconically concluded that VW could "put away its expansion plans for the US market" (Das Bild, 01).

Impact on profits. Finally, several journal articles explained that VW had to issue a profit warning as a result of the scandal, since the company decided to put 6.5 million euros into a special reserve meant to cover the potential cost of product recall and implementation. Das Bild noted how "the profit warning shocked the stock market" (Das Bild, 17) and Der Donaukurier remarked how the profit warning "nourish(ed) speculations about the future of the CEO a few hours before an emergency meeting was called by the company" (Der Donaukurier, 08).

Scandal spillovers. The sixth element we identified has to do with the potential negative spillovers of the scandal. These spillovers concern either the car industry or the German economy. 
Consequences for the car industry. Some articles mentioned the potential negative consequences of VW's wrongdoing on other "car producers" (Die Süddeutsche Zeitung, 03). Die Wolfsburger Allgemeine Zeitung and Die Süddeutsche Zeitung argued, respectively, that "Volkswagen is now in between a world-wide scandal that could affect the whole automotive industry" (Die Wolfsburger Allgemeine Zeitung, 04) and that "for the automotive industry, the image loss could be lethal" (Die Süddeutsche Zeitung, 08).

Consequences for the German economy. Other newspaper articles suggested that the VW scandal could be detrimental to the German economy as a whole. The argument here is that as "Volkswagen is the gem of the German economy," the company's wrongdoing could jeopardize “German engineering art, high technology, and top design" (Das Bild, 06). Alternatively, as Der Donaukurier put it, "since VW is a symbol of products from Germany, the scandal could damage other German exporters" (Der Donaukurier, 09).

Scandal Reputation Repair. The seventh and final element that we identified is reputation repair, which refers to newspaper discussions about how VW could repair their reputation.

Removal of CEO/executives. When the media framed the CEO and/or other executives as the main culprits for organizational wrongdoing, they also tended to advocate for their removal from the organization. The newspaper articles that we analyzed reported either the opinion of different influential stakeholders—all asking Winterkorn to step down-or at least asked whether he should step down. Das Bild observed how "Despite massive allegations, CEO Winterkorn does not think about stepping back" (Das Bild, 09), and harshly criticized his behavior. In a similar vein, 
Der Donaukurier stated that "VW needs a fresh start with new staff and without Winterkorn” (Der Donaukurier, 05).

Collaboration with authorities. In addition, most newspaper articles argued that the company's full cooperation with authorities was essential in order to regain the confidence of the market and the company's customers. For example, Das Bild maintained that:

"In order to overcome this image deterioration, the company has to explain in a convincing way what happened, and has to fully collaborate with the authorities" (Das Bild, 06).

To which Die Süddeutsche Zeitung added "the only way out for the company is to continue on this path of explanations and transparency" (Die Süddeutsche Zeitung, 30).

In the next section, we illustrate how each of the newspapers that we analyzed framed the VW scandal using the seven elements discussed above.

\section{Media Frames of the Volkswagen Scandal}

We found that each newspaper framed the VW scandal in a different way. Below we illustrate the four frames that we identified by using the seven elements of media framing illustrated above: nature of the scandal; identification of social-control agents that judge the misbehavior; locus of responsibility; reputational costs; financial costs; scandal spillovers; and scandal reputation repair. Table 1 summarizes the key characteristics of the frames that we identified.

Insert Table 1 about here 
Legalistic Frame (Das Bild). Das Bild uses a frame that we label as "legalistic". This frame describes the VW scandal mainly as a breach of the law perpetrated by the CEO of the company—and, to a lesser extent, by other executives—which would most likely result in financial costs for the company.

The frame points at the CEO as the main culprit for organizational wrongdoing. The newspaper ironically argues that it would have been extremely unlikely for a CEO that "was nominated Manager of the Year" in 2012 (Das Bild, 22) not to know what was going on inside his company. The newspaper further argues that, if he really did not know, this would be a good reason for him to step down as "he is no longer an acceptable part of the management team" (Das Bild, 04). This frame tends to downplay the role of other actors in the wrongdoing. Limited attention is paid to the other executives who were involved, although there is a tacit understanding that they did participate. Even less attention is paid to the role of the car industry in the wrongdoing.

Another characteristic of the frame under discussion is that it mainly focuses on the actual or potential financial costs associated with the scandal. The newspaper provides a number of estimates of the monetary sanctions that could be-and in some cases were-inflicted on VW, and discusses the stock market consequences of the wrongdoing in detail. In terms of monetary sanctions, Das Bild estimated that "because of the violations, Volkswagen risks a sanction of up to 18 billion US dollars!" (Das Bild, 01). In addition, the newspaper highlights how the shares of VW "crashed on the market" as a result of the wrongdoing (Das Bild, 08) and then "continued their decline" (Das Bild, 12) in the days after the EPA announcement. 
The newspaper does not discuss the nature of the scandal in detail. Although Das Bild explains that the scandal became public after the EPA's announcement that "the company was suspected of having used special software to manipulate the evaluation of pollutant emissions" (Das Bild, 03), and that the company later "admitted that over eleven million engines are equipped with this software" (Das Bild, 21), the newspaper seemed to be less interested in what the wrongdoing was about than in who was responsible and what the consequences may be-or already were-for the company.

Consistent with the view that the CEO is mainly responsible for the wrongdoing, and that the wrongdoing would most likely cost the company quite a lot of money, the newspaper points out that the replacement of the CEO is the most likely action to repair the company's reputation. Although a couple of articles suggest that "other executives must step down as well" (Das Bild, 34), most of the articles advocate for the CEO's replacement. The title of one of the articles that we analyzed is evocative in this respect: "the CEO of $V W$ drew the necessary conclusions from the gasmanipulation affair and stepped down. Drumrolls!” (Das Bild, 26).

Contextual Frame (Die Süddeutsche Zeitung). Die Süddeutsche Zeitung uses a frame that we label as "contextual." This frame portrays the VW scandal mainly as an event for which the company's executives and managers, as well as the car industry as a whole, are responsible.

The frame still depicts the company's executives and managers as the persons that are mainly responsible for the wrongdoing. In particular, most of the articles that we analyzed argue that:

"It is hard to imagine that the technician Winterkorn did not know (or at least suspect) what has become known in the United States: that VW deliberately and consciously manipulated the emission tests of over 400,000 diesel cars and, by 
doing that, deceived the authorities, its customers, and the public" (Die Süddeutsche Zeitung, 12).

However, the same articles also acknowledged the role of the industry in enabling — and sometime promoting —wrongdoing. One of the articles, in particular, reported the following joke, which clearly suggests that the car industry is by no means a virtuous, transparent environment:

"At the beginning of compliance courses for managers in the automotive industry, professors are used to telling the anecdote of the student who told the professor that he wanted to study business ethics. To which the professor replied dryly: I am afraid that you will have to decide for one or for the other" (Die Süddeutsche Zeitung, 07).

Consistent with this view of the car industry as being (at least partially) responsible for the wrongdoing, the newspaper under investigation discussed, quite extensively, the potential loss of trust in the company that resulted from the scandal and, more importantly, trust in the industry. According to the newspaper, VW "must make sure that its brand regains confidence" (Die Süddeutsche Zeitung, 32) and the industry needs to take all the actions necessary to "win its credibility back" (Die Süddeutsche Zeitung, 17). Confidence and credibility can be regained, according to the newspaper, primarily through full "cooperation with the authorities" (Die Süddeutsche Zeitung, 20). The newspaper also analyzed the financial costs associated with the scandal, focusing in particular on the possible monetary sanctions enforced on the company, but its discussion is not as extensive as that in Das Bild.

Finally, consistent with a more contextual account of the events under consideration, the newspaper spent quite a lot of time explaining the nature of the company's wrongdoing. For example, in just the first paragraph of one of the articles we analyzed, it was argued that "the car producer is reported to have violated 
American emission regulations," that "the US Environmental Protection Agency claims that the German car maker violated the Climate Protection Act," that "the company was suspected to have used special software to manipulate the evaluation of pollutant emissions," and that "using such means to circumvent the climate protection standards is illegal and a threat to public health" (Die Süddeutsche Zeitung, 02). All of these details, we believe, convey the idea that the nature of the wrongdoing is rather complicated and multifaceted.

Reputational Frame (Der Donaukurier). Der Donaukurier uses a frame that we label "reputational". This frame portrays the VW scandal as an event that could potentially destroy the company's reputation, and advocates for the replacement of the company's CEO as a means to signal the firm's willingness to have a "new beginning" (Der Donaukurier, 05).

The frame tends to concentrate on the loss of trust associated with the scandal, its possible consequences for the company-in particular, in terms of a reduction in the firm's accounting and market performance—and the effects of a possible product recall. According to the newspaper, VW is aware that "the trust of its customers and the public are and remain the most important asset of the Group" and that the company needs to "do everything in order to regain that trust" (Der Donaukurier, 02). Yet, they also need to face a situation in which "because of the diesel scandal, the confidence of many investors and buyers is gone or is-at least-severely damaged' (Der Donaukurier, 08).

The newspaper argues that the loss of trust in the company is likely to be associated with a sharp decrease in the company's performance. The frame under consideration highlights how, in addition to the immediate negative reaction of the 
stock market, VW could also experience a reduction in its profits. In particular, several of the articles we read highlight how "the (expected) costs for the improvement of the affected cars" (Der Donaukurier, 03) forced the company to issue a profit warning, as "6.5 billion euros were put aside for repairs" (Der Donaukurier, 07), obliging it to "adjust its earnings targets for 2015 accordingly" (Der

\section{Donaukurier, 07).}

In addition, the newspaper emphasized the possible negative consequences of a product recall for the company. Although the newspaper makes it clear that the EPA has "not arranged any formal recall yet" (Der Donaukurier, 06), the company may be required to "recall around 500,000 cars" (Der Donaukurier, 01), resulting in "additional costs" (Der Donaukurier, 06).

According to the newspaper, a first step in regaining the trust of the customers, and the public in general, is the replacement of the CEO of the company. The argument here is that the replacement of the head of the company can signal to the market that the company intends to change and, thus, can help to regain trust. In other words: "it is time that Winterkorn takes off his hat and that someone new steps in who can renew the company... Winterkorn has long lost the trust of consumers, as well as that of politicians” (Der Donaukurier, 04).

Scapegoating Frame (Die Wolfsburger Allgemeine Zeitung). Die Wolfsburger Allgemeine Zeitung uses a frame that we label "scapegoating". This frame mainly describes the scandal as being caused by a few individuals, in this case ruthless managers, who should be replaced. This frame tries to clearly separate their actions from those of the majority of VW's employees. 
The frame tends to identify the company's CEO and its executives as the principal culprits. In particular, the newspaper argues that "those responsible should be held accountable" (Die Wolfsburger Allgemeine Zeitung, 11) and asks "how stupid should one be to believe that managers did not know?" "How is it possible that something like that went unnoticed for so long? Or, did people in Wolfsburg also know something? There is quite a lot that people at Volkswagen should explain" (Die Wolfsburger Allgemeine Zeitung, 04).

However, the newspaper suggests that the actions of a few should not be confused with the good work done by the majority of employees. Alternatively, to use the newspaper's own words, "it would be wrong, if because of the grave errors of a few, the honest hard work of 600,000 people would be questioned...our employees do not deserve this" (Die Wolfsburger Allgemeine Zeitung, 28). These identical words were repeated in several articles, as were those reassuring the readers of the newspaper that “the company intends to take legal action against those responsible among VW's employees" (Die Wolfsburger Allgemeine Zeitung, 47).

In line with the idea that the company's CEO and other top managers are mainly responsible for the wrongdoing, the articles that we analyzed suggest that the replacement of the company's CEO and its executives is necessary in order to repair the company's reputation. The title and lead-in to one of these articles provides a good example: “Emission-gas scandal: Volkswagen fired top managers. The serious trust crises following the emission-gas scandal cost other top managers (in addition to Martin Winterkorn, the company's CEO) their jobs. Wolfgang Hatz, member of the Board of Directors at Porsche; Ulrich Hackenberg, Audi's Director of Development; and Heinz-Jakob Neußer, Volkswagen's Director of Development, had to go" (Die Wolfsburger Allgemeine Zeitung, 68). 


\section{Discussion}

Our analysis comprises two main sets of results. First, we analyzed the way in which four different German newspapers presented the VW scandal, and we identified seven elements that form the backbone of a general frame of corporate scandals. These seven elements are: nature of the scandal, social-control agents' judgment, locus of responsibility, reputational costs, financial costs, scandal spillovers, and scandal reputation repair. We compare our results with the four elements of the presidential scandal frame proposed by Entman (2012): problem definition, moral judgment, causal analysis, and endorsement of a remedy. Table 2 shows this comparison.

Insert Table 2 about here

We find many similarities, as well as a few differences, between our elements and the ones in Entman's political scandal frame (2012). There is a direct relationship between the four elements of Entman's political frame scandal (2012) and four of the elements that we coded for a corporate scandal media frame: problem definition, moral judgment, causal analysis, and endorsement of a remedy correspond to what we name as the nature of the scandal, social-control agents' judgment, locus of responsibility, and scandal reputation repair, respectively. Our labels differ slightly from the ones of Entman as they reflect differences between political and corporate contexts. For example, while moral judgment corresponds to what we call socialcontrol agents' judgment, in the case of corporate scandals it is not only about 
receiving "public moral condemnation from legitimate political actors" (Entman, 2012: 28); but there might be multiple social-control agents, some that ratify the wrongdoing (such as the EPA in our study) and others that morally condemn it (e.g., US politicians). In addition, Entman's causal analysis (2012)—which he describes as "the misdeed being clearly attributed to the individual president, vice president or candidate as a causal agent" (p. 28)—refers to what we name as locus of responsibility because, in the case of a corporate scandal, we found that the responsibility can be given to the CEO and specific executives, or to the broader context.

One main difference between our frame and that of Entman's (2012) is that we identify three more elements: reputational costs, financial costs, and scandal reputational spillovers. These elements are not spelled out in Entman's frame (2012), but they are particularly relevant in the case of a corporate scandal. There is a long tradition in organizational literature that discusses the reputational costs, financial costs, and reputational spillovers of wrongdoing. The weight that the media gives to each of these three elements is relevant because it can influence the public perception of how big the scandal is and, thus, how detrimental it will be for the company. This can in turn influence the behavior of important stakeholders of the company, such as business partners, who can decide to distance themselves from the wrongdoer (Sullivan et al. 2007).

A second main difference between Entman's model (2012) and ours is in the different saliency that the media gives to the elements of the scandal frames (the firstorder categories of Figure 1). This leads us to our next main result. We identify four different types of frames-legalistic, contextual, reputational, and scapegoating — that are used by each of the four newspapers that we analyzed. Each of these frames is 
characterized by the relative saliency that they place on each of the seven elements (e.g., "financial costs" vs. "reputational costs"), as well as within each of them (e.g. "CEO and executive responsibility" vs. "industry responsibility" within the "locus of responsibility" element). Again, this is relevant, as highlighting some elements at the expense of others can affect the public's perception of corporate scandals.

Our article makes multiple contributions to extant research. First, it contributes to the research on organizational wrongdoing by looking at the role of the media as a key social-control agent. The media is an important social-control agent that "has the ability to frame behaviors as misconduct and... put pressure on (other) social-control agents to put sanctions in place" (Greve et al. 2010 57). However, few studies have empirically investigated how the media reports instances of wrongdoing-despite broad recognition of its role in exposing and defining organizational wrongdoing. Our study fills this gap by analyzing how a sample of national and regional German newspapers frames the VW scandal. Our study shows that there is significant variation in the way in which newspapers report the VW scandal, thus supporting the social construction view of organizational wrongdoing.

Second, we extend and integrate recent studies that have investigated the media framing of scandals, but that have to date mostly been related to the political and sports contexts. We identify key elements of a general media frame of corporate scandals and investigate variations among newspapers. This corporate scandal frame could provide scholars with a common vocabulary and framework to describe instances of organizational wrongdoing, thus helping the comparison among different studies and the consolidation of existing knowledge. Also, the media is a key influencer of public opinion, and of the dynamics of a scandal. Therefore, an understanding of the specific media frames applied to an instance of wrongdoing can 
help with an understanding of the underlying theoretical mechanisms that scholars aim to explore. This is why we urge organizational scholars to report the specific media frames of organizational wrongdoing and scandals used in future studies.

Third, by exploring the frames that the media uses to report on organizational wrongdoing, our study brings insights from political science and mass communication research into organizational theory, thus advancing the research agenda of integrating these two disciplines (Clemente and Roulet 2015; Cornelissen et al. 2015). Political science and mass communication scholars have long recognized the role of the media in influencing public opinion (McCombs 2005; McCombs and Shaw 1972). Framing is one of the processes through which these scholars believe that the media can exert their influence. In this study, we look at framing processes in the context of an important organizational event: the occurrence of organizational wrongdoing.

\section{Limitations and future research}

This study advances the theoretical argument that there is variation within a country in the way in which the media frames an instance of organizational wrongdoing. This is important to understand as previous research shows that media framing is likely to influence interpretations of the wrongdoing and the consequences for the wrongdoer. However, each instance of wrongdoing presents some idiosyncrasies that set the boundaries of the external validity of our findings and, at the same time, opens up possibilities for future research. First, we considered one case of a fully developed scandal. We analyzed four major newspapers that gave the scandal significant visibility and that have different degrees of involvement with VW. Therefore, it is likely that we captured the main elements that constitute the general frame of corporate scandals (the seven second-order categories in Figure 1). However, 
one case cannot shed light on all of the options within each element (the first-order categories in Figure 1) or on all of the different types of media frames. Future research should assess how commonly the frames that we identified are used, and what other media frames exist.

In addition, we focus on an instance of wrongdoing that blew up into a scandal. While research in organizational studies has traditionally de-emphasized the distinction between organizational wrongdoing and corporate scandals (e.g., Jonsson et al. 2009), there is a growing scholarly interest in the distinction between these two concepts (Clemente and Gabbioneta 2016; Hirsch and Milner 2016). Future research should examine how the different elements of the media frame that we identified play out in organizational wrongdoing and do not play out in scandals.

Furthermore, future research may explore the frames used by other types of media, such as social media and television news. An analysis of social media may reveal interesting patterns, as these media sources have a more participative production mode than traditional media. On social media, anyone can publish news and opinions. While this poses some challenges in terms of authorship, it also represents a unique context in which to study how initial frames are picked up, elaborated on, or even discarded over time. Television news may be an interesting research context in which to explore how frames are created by the concurrent use of words and images. While newspapers may also include pictures, the images used in television news are likely to play a much bigger role in framing organizational wrongdoing. An analysis of the interplay between the textual and visual components of television news may reveal new, stimulating patterns in the framing of organizational wrongdoing. We hope that this study will prompt scholars to explore some of these fascinating research avenues 
in the future. In addition, we hope that this study will provide further impetus to academic research on the framing of organizational wrongdoing and scandals. 


\section{REFERENCES}

Adut, Ari. 2008. On Scandal. Cambridge University Press.

An, Seon-Kyoung and Karla K. Gower. 2009. "How Do the News Media Frame Crises? a Content Analysis of Crisis News Coverage." Public Relations Review 35(2):107-12.

Bennett, W L., Regina G. Lawrence, and Steven Livingston. 2006. "None Dare Call It Torture: Indexing and the Limits of Press Independence in the Abu Ghraib Scandal." Journal of Communication 56(3):467-85.

Boulding, Kenneth E. 1958. "Evidences for an Administrative Science: a Review of the Administrative Science Quarterly, Volumes 1 and 2." Administrative Science Quarterly 3(1):1-22.

Canel, Maria-Jose and Karen Sanders. 2006. Morality Tales. Hampton Pr.

Clemente, Marco and Claudia Gabbioneta. 2016. "A General Theory of Corporate Scandals." Helsinki.

Clemente, Marco and Thomas J. Roulet. 2015. "Public Opinion as a Source of Deinstitutionalization: a 'Spiral of Silence' Approach." Academy of Management Review 40(1):96-114.

Clemente, Marco, Rodolphe Durand, and Joseph F. Porac. 2016. "Organizational Wrongdoing and Media Bias." Pp. 435-73 in Organizational Wrongdoing, edited by D. Palmer, R. Greenwood, and K. Smith-Crowe.

Clemente, Marco, Rodolphe Durand, and Thomas Roulet. Forthcoming. "The Recursive Nature of Institutional Change an Annales School Perspective." Journal of Management Inquiry 1056492616656408.

Clinard, Marshall and Peter Yaeger. 1980. Corporate Crime. New York: Free Press.

Cohen, Jeffrey, Yuan Ding, Cédric Lesage, and Hervé Stolowy. 2015. "Media Bias and the Persistence of the Expectation Gap: an Analysis of Press Articles on Corporate Fraud." Journal of Business Ethics 1-23.

Corley, Kevin G. and Dennis A. Gioia. 2004. "Identity Ambiguity and Change in the Wake of a Corporate Spin-Off." Administrative Science Quarterly 49(2):173208.

Cornelissen, Joep P., Rodolphe Durand, Peer C. Fiss, John C. Lammers, and Eero Vaara. 2015. "Putting Communication Front and Center in Institutional Theory and Analysis." Academy of Management Review 40(1):10-27.

Desai, H, C E. Hogan, and M S. Wilkins. 2006. "The Reputational Penalty for Aggressive Accounting: Earnings Restatements and Management Turnover." The Accounting Review 81(1):83-112.

Diestre, Luis and Nandini Rajagopalan. 2014. “Toward an Input-Based Perspective on 
Categorization: Investor Reactions to Chemical Accidents." Academy of Management Journal 57(4):1130-53.

Entman, Robert and Andrew Rojecki. 1993. "Freezing Out the Public: Elite and Media Framing of the U.S. Anti-Nuclear Movement." Political Communication 10(2):155-73.

Entman, Robert M. 1993. "Framing: Toward Clarification of a Fractured Paradigm." Journal of Communication 43(4):51-58.

Entman, Robert M. 2012. Scandal and Silence. John Wiley \& Sons.

Entman, Robert M., Jörg Matthes, and Lynn Pellicano. 2009. "Nature, Sources, and Effects of News Framing." Pp. 175-90 in The Handbook of Journalism Studies, edited by K. Wahl-Jorgensen and T. Hanitzsch. Routledge.

Fiss, Peer C. and Paul M. Hirsch. 2005. "The Discourse of Globalization: Framing and Sensemaking of an Emerging Concept." American sociological review 70(1):29-52.

Gabbioneta, Claudia, Royston Greenwood, Pietro Mazzola, and Mario Minoja. 2013. "The Influence of the Institutional Context on Corporate Illegality." Accounting Organizations and Society 38(6-7):484-504.

Gamson, W A. and A Modigliani. 1989. "Media Discourse and Public Opinion on Nuclear Power: a Constructionist Approach.” American Journal of Sociology 95(1):1-37.

Garcia, Maria M. 2011. "Perception Is Truth: How U.S. Newspapers Framed the 'Go Green' Conflict Between BP and Greenpeace.” Public Relations Review 37(1):57-59.

Gioia, Dennis A. and Kumar Chittipeddi. 1991. "Sensemaking and Sensegiving in Strategic Change Initiation.” Strategic Management Journal 12(6):433-48.

Glaser, B G. and A L. Strauss. 1967. The Discovery of Grounded Theory: Strategies for Qualitative Research. NY: Aldine De Gruyter.

Greve, Henrich R., Donald Palmer, and Jo E. Pozner. 2010. "Organizations Gone Wild: the Causes, Processes, and Consequences of Organizational Misconduct." The Academy of Management Annals 4(1):53-107.

Harlow, Summer. 2012. "A Political Boss and the Press: the Impact on Democracy of Two Brazilian Newspapers.” Journalism 13(3):340-53.

Hirsch, Paul M. and Daniel Milner. 2016. "When Scandals Yield "It's About Time!" Rather Than "We"re Shocked and Surprised!'." Journal of Management Inquiry 25(4):447-49.

Iyengar, Shanto. 1990. "Framing Responsibility for Political Issues: the Case of Poverty." Political Behavior 12(1):19-40. 
Jensen, M. 2006. "Should We Stay or Should We Go? Accountability, Status Anxiety, and Client Defections." Administrative Science Quarterly 51(1):97-128.

Jonsson, Stefan, Henrich R. Greve, and Takako Fujiwara-Greve. 2009. "Undeserved Loss: the Spread of Legitimacy Loss to Innocent Organizations in Response to Reported Corporate Deviance." Administrative Science Quarterly 54(2):195-228.

Joslyn, M R. 2003. "Framing the Lewinsky Affair: Third-Person Judgments by Scandal Frame." Political Psychology 24(4):829-44.

Karpoff, Jonathan M., D S. Lee, and Valaria P. Vendrzyk. 1999. "Defense Procurement Fraud, Penalties, and Contractor Influence.” Journal of Political Economy 107(4):809-42.

Katz, Elihu, Hadassah Haas, and Michael Gurevitch. 1973. "On the Use of the Mass Media for Important Things.” American sociological review 38(2):164.

Kepplinger, Hans M., Stefan Geiss, and Sandra Siebert. 2012. "Framing Scandals: Cognitive and Emotional Media Effects." Journal of Communication 62(4):659682.

Kulik, B W. 2005. "Agency Theory, Reasoning and Culture at Enron: in Search of a Solution." Journal of Business Ethics 59: 347-360.

Lippmann, Walter. 1922. Public Opinion. New York: Macmillan.

Locke, Karen. 2001. Grounded Theory in Management Research. SAGE.

Matthes, Joerg and Matthias Kohring. 2008. "The Content Analysis of Media Frames: Toward Improving Reliability and Validity." Journal of Communication 58(2):258-79.

Matthes, Jörg. 2009. "What'S in a Frame? a Content Analysis of Media Framing Studies in the World'S Leading Communication Journals, 1990-2005." Journalism \& Mass Communication Quarterly 86(2):349-67.

McCombs, Maxwell. 2005. "A Look at Agenda-Setting: Past, Present and Future." Journalism Studies 6(4):543-57.

McCombs, Maxwell and D L. Shaw. 1972. "The Agenda-Setting Function of Mass Media." The Public Opinion Quarterly 36(2):176-87.

Merton, Robert K. 1938. "Social Structure and Anomie.” American sociological review 3(5):672-82.

Misangyi, Vilmos F., Gary R. Weaver, and Heather Elms. 2008. "Ending Corruption: the Interplay Among Institutional Logics, Resources, and Institutional Entrepreneurs." Academy of Management Review 33(3):750-70.

Nelson, T E., R A. Clawson, and Z M. Oxley. 1997. "Media Framing of a Civil Liberties Conflict and Its Effect on Tolerance." American Political Science Review 91(3):567-83. 
Nelson, Thomas E. and Donald R. Kinder. 1996. "Issue Frames and Group-Centrism in American Public Opinion." The Journal of Politics 58(04):1055-78.

Owen, D. 2000. "Popular Politics and the Clinton/Lewinsky Affair: the Implications for Leadership.” Political Psychology 21(1):161-77.

Palmer, Donald. 2012. Normal Organizational Wrongdoing. Oxford University Press on Demand.

Palmer, Donald, Kristin Smith-Crowe, and Royston Greenwood. 2016. Cambridge Companion on Organizational Wrongdoing: Key Perspectives and New Directions. Cambridge University Press.

Pan, Zhongdang and Gerald Kosicki. 1993. "Framing Analysis: an Approach to News Discourse." Political Communication 10(1):55-75.

Paruchuri, Srikanth and Vilmos F. Misangyi. 2015. "Investor Perceptions of Financial Misconduct: the Heterogeneous Contamination of Bystander Firms." Academy of Management Journal 58(1):169-94.

Riffe, Daniel. 2004. “An Editorial Comment.” Journalism \& Mass Communication Quarterly 81(1):2-3.

Roulet, T. 2015. “"What Good Is Wall Street?' Institutional Contradiction and the Diffusion of the Stigma Over the Finance Industry." Journal of Business Ethics 130(2):389-402.

Sanders, Karen and Maria-Jose Canel. 2006. "A Scribbling Tribe Reporting Political Scandal in Britain and Spain." Journalism 7(4):453-76.

Semetko, H A. and P M. Valkenburg. 2000. "Framing European Politics: a Content Analysis of Press and Television News." Journal of Communication 50(2):93109.

Sims, Ronald R. and Johannes Brinkmann. 2003. "Enron Ethics (or: Culture Matters More Than Codes)." Journal of Business Ethics 45(3):243-56.

Staw, Barry M. and Eugene Szwajkowski. 1975. "The Scarcity-Munificence Component of Organizational Environments and the Commission of Illegal Acts." Administrative Science Quarterly 20(3):345.

Steininger, Michael. 2012. "German Tabloid Bild Takes Down Politicians with Its Unmatched Megaphone.” Retrieved September 2, 2016 (http://www.csmonitor.com/World/Europe/2012/0118/German-tabloid-Bildtakes-down-politicians-with-its-unmatched-megaphone).

Stepanova, E V. and M J. Strube. 2009. "They Saw a Triple Lutz: Bias and Its Perception in American and Russian Newspaper Coverage of the 2002 Olympic Figure Skating Scandal1.” Journal of Applied Social Psychology 39(8): 17631784.

Sullivan, Bilian N., Pamela Haunschild, and Karen Page. 2007. "Organizations Non 
Gratae? the Impact of Unethical Corporate Acts on Interorganizational Networks." Organization Science 18(1):55-70.

Thompson, John B. 2000. Political Scandal. John Wiley \& Sons.

Vaughan, D. 1999. "The Dark Side of Organizations: Mistake, Misconduct, and Disaster." Annual Review of Sociology 25: 271-305

Whetten, David A. 1989. "What Constitutes a Theoretical Contribution?." Academy of Management Review 14(4):490-95.

Yang, Michelle M. 2014. "Guilty Without Trial: State-Sponsored Cheating and the 2008 Beijing Olympic Women's Gymnastics Competition.” Chinese Journal of Communication 7(1):80-105. 
Figure 1. Data Structure

Raw data (exemplars translation by the authors)

The charges: embezzlement, false advertising, and breach of laws
(SZ, 25)

In its statement, the EPA talked about a technique for circumventing the rules (DK, 01).

We are "quite concerned" about the behavior of VW, said a spokesman for President Obama (SZ, 15).

Winterkorn is no longer considered an acceptable member of the management team (WAZ, 06)

VW was cheating - as were all of the others $(\mathrm{SZ}, 08)$

Something like this not only costs billions. It also destroys the company's image (SZ, 03)

I personally deeply regret that we have betrayed the trust of our customers and the public (SZ, 04)
First-order categories

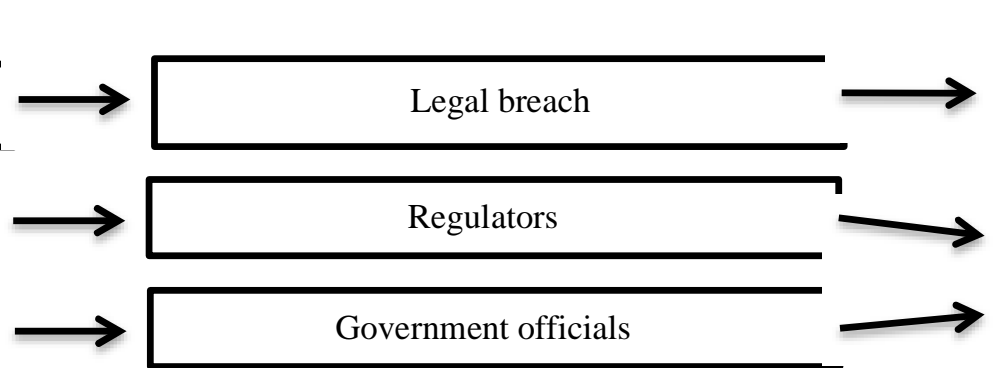

Second-order categories

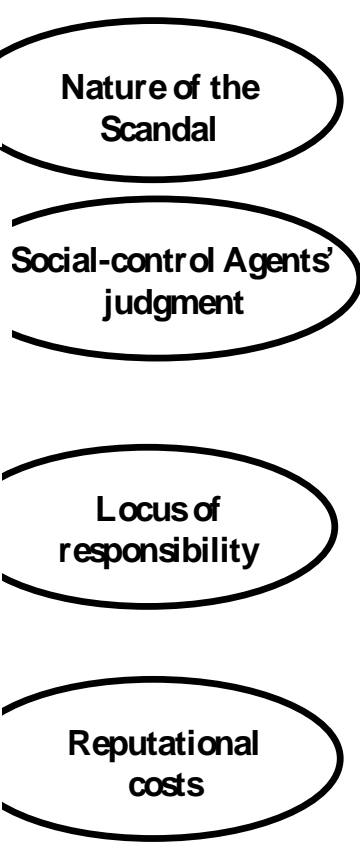

\section{costs}

CEO and executive responsibility

Industry responsibility

Image deterioration

Trust loss
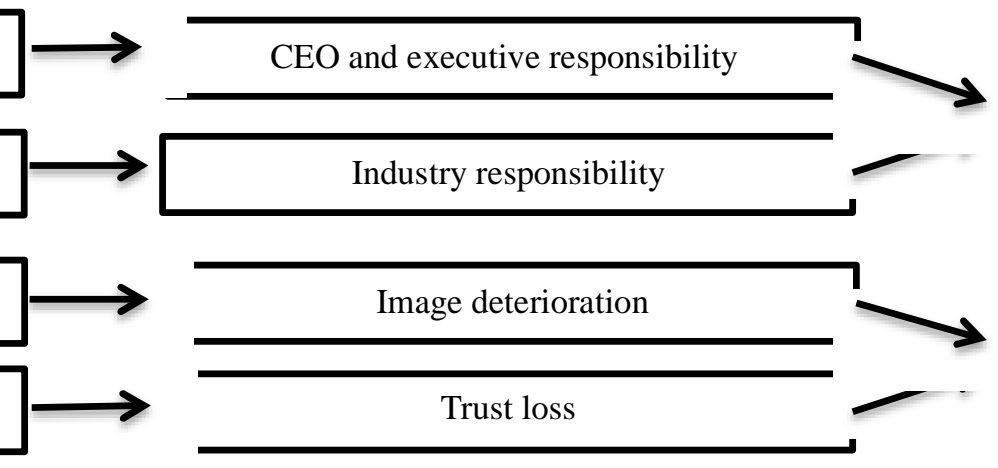
Figure 1. Data Structure (continued)

\section{Raw data (exemplars - translation by the authors)}

First-order categories

Second-order categories

Volkswagen worries about high fines in the United States (SZ, 02)
Recall of 482,000 diesel vehicles in California (DB, 03)
Shares crash after Diesel disaster (DB, 08)
into reserves, he said (DB17)
industrv (SZ. 03)
$\begin{aligned} & \text { DiW warned about the massive consequences of the scandal for } \\ & \text { the German economv (DK. 06) } \\ & \text { Fould be the most elegant solution (DK. 08) }\end{aligned}$
First, they would "cooperate with competent authorities" (SZ, 04).


Table 1. Main Characteristics of the Frames that Newspapers Use

\begin{tabular}{|c|c|c|c|c|}
\hline Newspapers & Das Bild & Die Süddeutsche Zeitung & Der Donaukurier & Die Wolfsburger A. Zeitung \\
\hline Type of Frame & Legalistic & Contextual & Reputational & Scapegoating \\
\hline Description & $\begin{array}{l}\text { The scandal as a breach of the law } \\
\text { with legal consequences }\end{array}$ & $\begin{array}{l}\text { The scandal as an event } \\
\text { happening at the intersection of } \\
\text { the company and the car industry }\end{array}$ & $\begin{array}{l}\text { The scandal as an event that could } \\
\text { potentially destroy the trust that } \\
\text { customers have in the company }\end{array}$ & $\begin{array}{l}\text { The scandal is caused by a few } \\
\text { individuals, in this case ruthless } \\
\text { managers, who should now be } \\
\text { replaced }\end{array}$ \\
\hline Nature of scandal & $\begin{array}{l}\text { Limited discussion of nature of } \\
\text { scandal }\end{array}$ & $\begin{array}{l}\text { Broad discussion of nature of } \\
\text { scandal }\end{array}$ & $\begin{array}{l}\text { Broad discussion of nature of } \\
\text { scandal }\end{array}$ & Broad discussion of nature of scandal \\
\hline $\begin{array}{l}\text { Social-control agents' } \\
\text { judgment }\end{array}$ & $\begin{array}{l}\text { Regulator (EPA) and US } \\
\text { government officials }\end{array}$ & $\begin{array}{l}\text { Regulator (EPA) and US } \\
\text { government officials }\end{array}$ & $\begin{array}{l}\text { Regulator (EPA) and US } \\
\text { government officials }\end{array}$ & $\begin{array}{c}\text { Regulator (EPA) and US government } \\
\text { officials }\end{array}$ \\
\hline $\begin{array}{l}\text { Locus of } \\
\text { responsibility }\end{array}$ & $\begin{array}{c}\text { Mainly CEO responsibility } \\
\text { (but some recognition of executive } \\
\text { responsibility) }\end{array}$ & $\begin{array}{l}\text { Mainly CEO and industry } \\
\text { responsibility }\end{array}$ & $\begin{array}{l}\text { Responsibility is not discussed } \\
\text { extensively }\end{array}$ & $\begin{array}{l}\text { Mainly CEO and executive } \\
\text { responsibility }\end{array}$ \\
\hline Reputational costs & $\begin{array}{l}\text { Some discussion of image } \\
\text { deterioration and loss of trust }\end{array}$ & Some discussion of loss of trust & Broad discussion of loss of trust & Some discussion of loss of trust \\
\hline Financial costs & $\begin{array}{c}\text { Broad discussion of monetary } \\
\text { sanctions and stock market effects }\end{array}$ & $\begin{array}{c}\text { Broad discussion of monetary } \\
\text { sanctions and stock market effects }\end{array}$ & $\begin{array}{l}\text { Broad discussion of stock market } \\
\text { effects, discussion of costs of } \\
\text { product recall and impact on } \\
\text { profits }\end{array}$ & $\begin{array}{c}\text { Broad discussion of monetary } \\
\text { sanctions and stock market effects }\end{array}$ \\
\hline Scandal spillovers & $\begin{array}{l}\text { Discussion of the consequences for } \\
\text { the German economy }\end{array}$ & $\begin{array}{l}\text { Discussion of the consequences } \\
\text { for the car industry }\end{array}$ & $\begin{array}{c}\text { Limited discussion of } \\
\text { consequences for the German } \\
\text { economy or the car industry }\end{array}$ & $\begin{array}{l}\text { Discussion of the consequences for the } \\
\text { car industry }\end{array}$ \\
\hline $\begin{array}{l}\text { Scandal reputation } \\
\text { repair }\end{array}$ & $\begin{array}{l}\text { Broad discussion of VW reputation } \\
\text { repair (mainly CEO replacement) }\end{array}$ & $\begin{array}{l}\text { Broad discussion of VW } \\
\text { reputation repair }\end{array}$ & $\begin{array}{l}\text { Broad discussion of VW } \\
\text { reputation repair (mainly } \\
\text { replacement of CEO and } \\
\quad \text { executives) }\end{array}$ & $\begin{array}{l}\text { Broad discussion of VW reputation } \\
\text { repair (mainly replacement of CEO } \\
\text { and executives) }\end{array}$ \\
\hline
\end{tabular}


Table 2. Comparing the Elements of a Corporate Scandal Frame and a Political Scandal Frame

\begin{tabular}{|c|c|c|c|}
\hline First-order categories & $\begin{array}{l}\text { Elements of a corporate } \\
\text { scandal frame }\end{array}$ & $\begin{array}{c}\text { Elements of a presidential } \\
\text { scandal frame (Entman, } \\
\text { 2012) }\end{array}$ & $\begin{array}{c}\text { Description } \\
\text { (Entman, 2012: 28) }\end{array}$ \\
\hline - Legal breach & The nature of the scandal & Problem definition & $\begin{array}{l}\text { "the behavior be defined as a problem impeding or } \\
\text { threatening the proper operation of government or } \\
\text { society" }\end{array}$ \\
\hline $\begin{array}{ll}\text { - } & \text { Regulators } \\
\text { - } & \text { Government officials }\end{array}$ & $\begin{array}{l}\text { Social-control agents' } \\
\text { judgment }\end{array}$ & Moral judgment & $\begin{array}{l}\text { "the misconduct and the responsible leader receive } \\
\text { public moral condemnation from legitimate political } \\
\text { actors" }\end{array}$ \\
\hline $\begin{array}{l}\text { - } \quad \text { CEO and executive responsibility } \\
\text { - } \quad \text { Industry responsibility }\end{array}$ & Locus of responsibility & Causal analysis & $\begin{array}{l}\text { "the misdeed [is] clearly attributed to the individual } \\
\text { president, vice president or candidate as a causal } \\
\text { agent" }\end{array}$ \\
\hline $\begin{array}{ll}\text { - } & \text { Image deterioration } \\
\text { - } & \text { Trust loss }\end{array}$ & Reputational costs & - & - \\
\hline $\begin{array}{ll}\text { - } & \text { Monetary sanctions } \\
\text { - } & \text { Costs of product recalls } \\
\text { - } & \text { Stock market effects } \\
\text { - } & \text { Consequences on customer markets }\end{array}$ & Financial costs & - & - \\
\hline $\begin{array}{l}\text { - } \quad \text { Consequences for the car industry } \\
\text { - } \quad \text { Consequences for the German economy }\end{array}$ & $\begin{array}{l}\text { Scandal reputational spill- } \\
\text { overs }\end{array}$ & - & - \\
\hline $\begin{array}{ll}\text { - } & \text { Removal of CEO/Executives } \\
\text { - } & \text { Full collaboration with authorities }\end{array}$ & Scandal reputation repair & Endorsement of a remedy & $\begin{array}{l}\text { "a remedy involving sanction against the individual } \\
\text { [is] widely demanded or debated" }\end{array}$ \\
\hline
\end{tabular}

